\title{
The Mistress of Spices - A Memorable Work of Chitra Banerjee Divakaruni in Indian Fiction
}

\author{
CH. Aruna \\ Lecturer in English, Hindu College, Guntur \\ arunach789@gmail.com
}

\begin{abstract}
In fact Literature has always been an effective instrument in the hands of mankind since time immemorial and contributed for the all round development of the human beings and for bringing harmony among different cultures and societies. There are several forms of Literature but Drama, Poetry, Short story and Novel occupies the major part of literature. What so ever be the form all literary works can be placed in a particular context. In other words, all literary works are written at a particular time amidst many social changes. So when we study a literary text it would help us to know more about these contexts or when and where it was written and what was happening in the society then. Myths and histories are written about them and a strong sense of national and cultural identity is constructed through writing.

Chitra Banerjee Divakaruni has characterized the lifless spices as living characters in her novel. The Mistress of spices the Indo American Woman writer Divakaruni has given metaphorical representation to the Indian spices in order to touch upon the knowledge beyond science. It also depicts the representation of different myths, magic and history, related to spices. It also evaluates the importance of spices in Socio-Cultural perspective in the life of protagonist. Chitra Banerjee Divakaruni has been able to produce the better meaning of the text and context by characterizing the spices as non-human beings.
\end{abstract}

Keywords: Spices, Post colonial, myth, magic, mistress.

\section{INTRODUCTION}

The novel is the most important and popular literary medium in the modern times. It is the only literary from which can compete for popularity with the film and the radio, and it is in this form that a great deal of distinguished work is being produced. The publication of a new novel by a great novelist received now with the same. Being influenced by the scenario of Indian women novelists, Chitra Bannerjee Divakaruni also shows her intentions in literature. It is evident from her life history.

Chitra Banerjee, born in India and migrated to United States was one of the Women Novelists that belong to the area of Asian American Literature which falls under the head of Common Wealth Literature. She is an award winning author and poet. Her work is widely known, as she has been published in and over 50 magazines including the "Atlantic Monthly' and "The New Yorker" and her writing has been included in 50 anthologies. Her works have been translated into 13 languages including Dutch, Hebrew, Russian and Japanese.

She was born in India and lived there until 1976, at which point she left Calcutta and came to the United States. She continued her education in the field of English by receiving a Master's Degree from Wright State University in Dayton, Ohio and a Ph.D., from the University of California, Berkeley in 1985. Christopher Marlow was the subject of her doctoral dissertation.

To earn money for her education, she held many odd jobs including babysitting, selling merchandise in an Indian boutique, slicing bread in a bakery, and washing instruments in a science lab, etc., At Berkeley she lived in the International House and worked in the dining hall. She briefly lived in Illionois, Ohoio and Texas, but has spent most of her life in Houston with her husband Murthy, her two sons Anand and Abhay (Whose names she has used in her children's novel's) and Juno, the family dog.

Much of Divakaruni's work deals with the immigrant experience, an important theme in the mosaic of American society. She writes to unite people. Her aim is to destroy myths and stereo types. She hopes 
through her writings to dissolve boundaries between people of different backgrounds, communities, ages and even different worlds.

The main objective of this paper is a quick look at Chitra Banerjee Divakaruni's "The Mistress of Spices", as a novel set in the post colonial Society and how the Characters face the trauma even is the post colonial time.

There is an argument that post colonial theory functions as a sub within the division within the field of "cultural studies" and includes leftist and feminist schools of thought among others. A simplistic literary approach to the term "Post Colonial literature" would apply it to literature written by writers about people living in countries formerly colonized by other nations. This we believe is certainly what the term must have originally meant. In this paper's a quick look at Chitra Banerjee Divakaruni's "The Mistress of Spices", as a novel set in post colonial society and how the characters face the trauma even in post colonial life.

It is said that in Indian English Literature post colonialism can't be viewed as a contrasting stand point or a sudden deviation from the literature produced during the colonial rule. In fact, the denunciation of the colonial rule, even in India, was much more vocal even under foreign rule. Colonialism is an event in the history of a nation which can be identified in a chronological manner. Colonial domination must have come about at a particular period in the history of a country and the effect and characteristics of such a rule reveal themselves in various aspects of life. Scholars say that in a broader sense the term postcolonialism may be seen as "an opening of a field of enquiry and understanding following a period of colonial rule".

Under colonialism the subject had "a way of maintaining an unequal interrelation of economic and political power". Colonial rule had its impact on political, social, cultural, economic and even religious life of the people and in all these institutions the repressive influence of the state machinery is felt.

Colonialism is thus a totalitarian experience which systematically programmed colonized people to understand themselves as other, marginalized, in relation to this center. Colonization can't be viewed just as a political and economic subjugation of country, but rather prolonged as a program of cultural colonization to support and maintain the domination of the colonizers.

"The Mistress of Spices" is a unique novel. It is written with a blend of prose and poetry. The novel is full of mystical turns and magical spells. She views that:

I wrote in a spirit of play, collapsing the divisions between the realistic world of twentieth century America and the timeless one of myth and magic in my attempt to create a modern fable.

She fuses myth with magic and gets success in achieving the, literary flavors. If T.S. Eliot uses the theory of "Tradition and Individual Talent", as his literary vehicle, Virginia Wolfs the 'steam of consciousness', Mathew Arnold's "The Touch stone method", Chitra Banerjee uses myth and magic to achieve her literary effects.

Tilo, a magical figure runs a grocery shop. She uses spices to help the customers to overcome difficulties. She sells and even provides spices according to their suited problems and troubles. She provides spices not only for cooking, but also for the homesickness and alienation that the Indian immigrants in her shop experience. In fact, not only the Indian immigrants flock to the shop but also the original inhabitants come to her shop with an intention of getting healed. In this process, she develops dilemmas of her own when she falls in love with a non-Indian, which is against the rules of mistresses. As well as that may effect her in losing her powers on the spices. This creates great conflict. She has to choose whether to serve her people or to follow the path leading to her own happiness. Tilo has to decide which parts of her heritage she will keep and which parts she will chose to abandon. In this direction of the novel the story is well knit and well - designed.

".........brush the surface with your hand and the silk yellow powder will cling to the pads of your palm, to your finger tips. Dust froma butterfly wing."

Bring it to your face. Rub it on cheek, forehead, chin. Don't be hesitant. For a thousand years before history began, brides and those who long to be brides, have done the same. It will erase blemishes and wrinkles suck away age and fat. For days afterward, your skin will give off a pale golden glow. 
Tilo, the protagonist of the novel is not just a magical figure who runs a grocery shop, she is more than that. In fact, she doesn't work for herself alone. She is the bridge between herself and the sufferers. She is an elegant advisor, an up bringer of healing powers, a remedial champion. How does she possess these magical powers? Is it possible? Is it real? All these questions coming to one's mind is secondary and dismissal. She can be accepted as she is a life giver, restorer of health and hope. She admits frankly and says that she is a mistress of spices. "She can work the others too like mineral, metal, earth and sand and stone, the gems with their cold, clear light; the liquids that burn their hues into our own eyes till we see nothing else."5 She learned them on the island of spices.

She knows their origin, and what their colors signify and their smells. She can call each by their true name it was given at the first, when the earth split like skin and offered it up to the sky. Their heart runs in her blood.

"At a whisper they yield up to me their hidden properties, their magic powers...........the spices of true power are from my birth land, land of ardent poetry, aquamarine feathers...".

Here, we should notice one important thing and observe few fulminating remarks within ourselves. She doesn't give the impression that she is trying to explain the stand of women. It made women realize that gender is a social construct that needs to the deconstructed. She is not giving a call to rebel against their exploitation and marginalization. At the same time, she is not setting the standards of womanhood, set by men for men, they sought to redefine themselves by their own standards or to reorder the society. She doesn't want to play the stereotype one's of sacrificing mother, complaint wife or docile daughter. She just wants to find remedial capsules for the suffering people surrounded by her. As Pat Conray points out:

'A Splendid novel, beautifully conceived and crafted'.

TILO, the protagonist of the novel was born in a lower class family as a third girl child and was felt burden by her parents as another dowry debt. As the cows run dry at the time of her birth she was fed with the milk of ass which helped her in getting the sight and words sooner than others. Being neglected by her parents she led a very careless life. When born she was named NAYAN TARA - The star of the eye, star seer, and also the flower that grows by the dust road. However, when she realized her unknown powers and helped the villagers in solving their problems and finding their lost things she was given luxurious presents as a matter of gratitude and her household won recognition. A girl who was once neglected was now chosen to be the best. Once she was last for anything but now she was the first for everything. Even the family members enjoyed the luxury life brought by the fame of her exotic powers. She too has grown proud and willful. But this does not last long. Her fame spreads far and wide. By her powers she can draw to her whoever she wishes - a lover to her side or an enemy to her feet. But when used imperfectly and without control can bring destruction beyond imagination.

Once when she was a child out of boredom and discontentment, she sent a calling thought with a gold hook over the waters by which pirates came in search of her and took her away killing her parents and destroying the village with fire, so as to gain more and more riches with her exotic powers. Then only she learned the truth that The Spell is greater than the Spell maker, once unleashed it cannot be countered'. For some years she lived as a Queen of Pirates - bringer of death and luck. As a pirate queen she reviews her life and wants to know her longing and sends a calling thought over the water again. As a result a typhoon came in the water she was released and saved by the serpents of under water.

Serpents are the oldest creatures and the dearest to the Earth Mother. They have perfected the art of invisibility, if they do not wish, one can never see them. Serpents told her about the Island of spices, the place where if she reaches would lose everything, sight, voice, name and perhaps self. Though they could see the spice glow under her skin - the sign of her destiny, they offer her to become sarpa kanya, but she feels the Island is waiting for her. She feels The Island of Spice' a name for my wanting. Returning from serpents she made the sailors drove aimlessly. At last she made them anchor at one place and at midnight she jumps into the ocean hoping to reach the Island of Spices. In the morning she found herself naked on the shore. As soon as she opened her eyes she found First Mother and her novices. When the old mother took her hands into hers they were too hot and damp. Though they were not suitable hands spices sang back to her. She did not remember her past. 
Here under the guidance of First Mother she renames herself as TILOTTAMA - It means Life giver, restorer of health and hope. Tilo is the sesame seed of which the flower is so small and straight that mothers pray for their children to have a nose shaped like it. It is golden brown in color under the sway of planet Venus. Til when ground into paste with sandal wood cures diseases of heart and liver. When fried in its own oil restores luster when one has lost interest in their life. Tilottama is the most beautiful Apsara in the court of God Indra. She is the most elegant of all dancers. She was crest jeweled among women. She being the chief dancer of the Indra's court she was warned never to give her love to any man but only to dance. When she disobeyed she was banished to live on the Earth the seven lives of mortal facing illness and age, twisted leprons and limbs and even people turning in disgust from her.

Along with her other friends Aparajita - a flower whose juice when smeared on eyelids leads one to victory and Pia - the tree whose ashes rubbed on limbs brings vigour, Tilo passed the ceremony of purification i.e., entering the Shampati's fire. The first time you enter the shampati's fire - you will not burn, you will not feel pain and you will wake in your new body as though it has been yours forever - a body that has lost its youth and took on age and ugliness and unending service. Tilo was the brightest pupil of old mother as well as the rule breaker. She is quick to master every spell and chant and as quick even to speak with the most dangerous spices. She is quick in arrogance and impatience too.

When she heard about Tilottama she decided that she will not fall like her She says:

"I need no pitiful mortal man to love. I believe this wholly".

"My heart is filled with passion for the spices, my ears with the music of

Our dance together, my blood with our shared power".

Along with other things the mistresses learned certain common things such as sweeping, stitching, rolling wicks for lamps, gathering wild spinach, roasting chapattis, braiding each other's hair etc., They even learned to feel without words the sorrows of other sisters, and to console them without words. The life of mistresses would be full of exotic, mystery, drama and danger. Once in a great while if a mistress grows rebellious and self indulgent, fails her duty she must be recalled. Warning is sent to her and she would have only three days to settle her affairs. Then Shampati's fire blazes for her once again. But this time while entering the fire one would feel it fully scorchy and sears. The razors of flame cutting her flesh to strips, screaming she smells her bones shatter, skin bubble and burst. Then the Spices decide - some mistresses are allowed to return to the Island, learn and labor again, for some it is the end crumbled charcoal, a last cry dangling in the air like a broken cobweb.

Soon after the training was over First Mother offered to choose the places to settle themselves. Tilo chooses Oakland The Old mother warns her against it and offers to chose another place but Tilo insists on the same First Mother developed a kind of liking towards Tilo from the beginning hence guides her at every moment. Old one gave each Mistress a going away gift. Some got flutes, incense burners, some looms and some pens but Tilo alone got a Knife, to keep under mattress before sleeping, to keep her chaste and from dreaming. The Knife is as cold as ocean water, supple edged as the yucca leaf that grows high on the sides of the volcano. The Old one taught Tilo to look into the heart of others but she doesn't teach her to read the future as it keeps her away from hoping and trusting the spices fully.

While Tilo was about to leave the Island of Spices to America First Mother, from the folds of her clothing placed a slice of ginger root to give her heart steadfastness and to keep her strong in her vows. The taste of ginger root is the last taste of Island and first taste of America.

Tilo loves spices, knows their origins, what their colors signify, their smells and even their true names. Their heat runs in her blood. From Amchur to Zafran all bow to her command, yield their properties and magic powers. Every Indian spice was found in her store and when placed in her hand they speak to her and even direct her at necessary times. SPICE BAZAAR was the name of her shop fitted at the corner. The board faded into mud brown. Though the shop is been there for only a year, it looks as though it was there from many years. The walls inside the shop were veined with cobwebs and metal bins lost their shine. In the corner of the shop dust balls ere accumulated along with the desires exhaled by the customers. 
She is a bent woman with skin, the color of old sand - but really she is not that old. In her body except her eyes nothing is her own but the body she got on in shampati's fire. By her looks she was considered by some as witch woman but when they face problems they come to her for solutions. As a Mistress it is her duty to understand their longings for the ways they chose to leave behind when they chose America without their revealing.

Each chapter of this novel is named after a spice which reveals their powers and their origins and thus making the novel very interesting to the reader to continue without postponing. In the chapters she deals with different problems faced by women and even found a solution for them, healing them with the help of spices.

She just doesn't want needs for physical satisfaction or ailments but for emotional satisfaction and ultimately leads to spiritual contentment.

People who are disturbed in the society, suffers from alienation and isolation or who suffers with the internal struggle ensures to come to terms with this lady. The painful process of resolving the conflict within themselves many times difficult. For them she is human goddess to resolve their problems.

Even, Tilo who runs the grocery shop runs after the problems in spite of her limitations and bounded promises, She is the care taker of human problems and their ups and downs.

Turmeric, also named Halud meaning yellow, color of day break, corals and shell sound is used as a shield for heart's sorrow, an ointment for death and hope for rebirth. It is placed on the heads of new born for luck, sprinkled over coconuts at puja, rubbed into the borders of new and even wedding saris. When rubbed on skin it erases, blemishes and wrinkles, sucks away age and fat and gives the skin a pale golden glow. Cinnamon or Dalchini is a friend maker and a destroyer of enemies, and gives strength in legs, arms and mouth. Fenugreek, the speckled seed first sown by Shabari, oldest woman in the world, renders the body sweet again ready for loving. Dhania or Coriander seed is used for clearing sight. When you soak it and drink the water it purges you of old guilts. Amchur is used to heal the taste buds and bring back love of life.

Dhania - coriander seed - used for clearing sight - when you soak it and drink the water it purges you of old guilts.

Arnchur is used to heal the taste buds and brings back the love oflife.

Mahamul - the root spice is used to enhance fortune, to bring success of joy and to avert ill luck.

Tulsi - the basil plant of humility. It is the curber of ego. It slakes the craving for power, turns the thoughts inwards and away from worldliness.

Hartuki - shriveled seed in the shape of a womb - helps mothers to bear the pain that starts with birthing.

Astringent leaf dried dark on the stem is used to reduce mistrust and avarice.

Black pepper is boiled and drunk to losen the throat and learn to say 'No -and hear me no' which is so hard for Indian women.

Powder of almond and kesar to boil in milk, to drink at bed time to sweeten your words and thoughts to remember the love buried under the anger.

Fenugreek, the Tuesday's spice is as fresh as river wind to the tongue. It plants desire in a plot which turned even barren. It renders the body sweet again ready for loving. It as told that this speckled seed was first sown by Shabari - the oldest woman of the world.

Fennel- the spice of Wednesday - the day of averages of middle aged people. It is as brown as mud and dark and leaf dancing in a fall breeze, smelling of changes to come. Fennel when taken a pinch of it raw and whole after every meal freshens the breath and helps digestion. It gives mental strength for what must be done. It even cools the temper. It is a spice to digest sorrows and makes strong. It is the equalizer too. When two people eat this at the same time it takes the power from the one and gives it to the other. 
The Elephants places on the desk in the bazaar symbolizes the promises remembered and kept. Sandal wood is used for soothing for over hurt, and the Ivory is used for endurance. The ingredient of Turmeric' is also explained in symbolic language .It is set in the bin by the entrance. It is also named Halud meaning Yellow, color of day break, corels and shell sound. It is a shield for heat's sorrow, an ointment for death and hope for rebirth. It is placed on the heads of new born for luck. It will be sprinkled along with the coconut water at the time of performing 'pujas'. It will be rubbed into the borders of new sarees and wedding clothes. When it is rubbed on skin, it erases, blemishes and wrinkles. It reduces the age, fat and makes the skin to glow. The mistress uses the turmeric for healing effects.

Cinnamon or dalchini is a friend maker and destroyer of enemies. It even gives strength in legs arms and mouth.

Makaradwaj - the king of spices is the conqueror of time. It is used to attain beauty. When one thousandth of it is mixed with milk and amla fruit and sipped slowly one spoon every hour for three days and three nights gives enormous beauty.

Lotus root is used for passionate loving and long living Red Chillies the most potent of the spices are also used. These were originated in Lanka whose other name is danger. Lanka- the fire child is the cleanser of the evil when there is no other way. Chillies are said to be born out of Agni. The god of Fire. He dripped his finger tips to the chillies to bring taste to this bland earth. This is the spice of red and the Thursday spice. Thursday is the day of both murder and suicide. Lanka represents the ten headed Ravana and his city of million jewels which at last turned to ash.

Mistresses are not allowed to learn about the usage of red chillies until the third level of apprenticeship. As they are most dangerous, they should be used only as a last remedy. Mistress' were warned against its powers, as First Mother says; 'It is easy to start a flame but not to put it out'.

Though many comes to her shop Tilo tempts to speak only to a few of them. Some of them were Lalitha, Haroun, Jagjit, Kwesi, Geeta and her grandfather, Lateefa and the last but not the least is the lonely American.

Lalitha, Ahuja's wife, before her marriage hopes to have a shop of her own - Lalitha Tailor works as the cloth she touches with the needle blooms, and most of all she wants a baby to make everything right for her feelings. When she goes for a checkup and found everything right with her, she requests her husband too for a checkup, who inturn beats her mercilessly, with which Lalitha gets fed up and with the help of a helpline found in a magazine, gets over from there taking her things and the jewelery and decides not to go back to him.

Haroun who runs shikaras for tourists in Srinagar, escaped to America when rebels broke out in their place. For some days he worked under Kapadia but luckily found another kashmiri who helped him to become a owner of his own cab. It is for him the mistress breaks some rules which drives her to destruction.

Geeta, though daughter of an Indian family but brought up in the American land strives for independence. But her grandfather who hailed to America only to be with his son always longs to go back to his native land India. It is through this family Divakaruni reflects the Indian cultures. Tilo tries to unite the grand daughter and the father and the grandfather who broke away from their ties when Geeta wishes to marry an American.

Jagjit, meaning the world conqurer, was a sikh boy who at the beginning of the novel, was a boy who holds the sare ends of his mother has been completely changed as spices started working against him. Tilo tries her best to restore him by the end of the novel.

"Lanka, Lanka sometimes I roll your name over my tongue. Taste the enticing sting of it. So many times the old one has warned us against your powers".

"Daughter use it only as the last remedy. It is easy to start a flame. But to put it out?"

That is why I hold on, Lanka, Whose name the ten headed Ravana took for his enchanted kingdom. City of million jewels turned at last to ash. 
Though more than once I have been tempted, as when Jagjit comes to the store. In the inner room of the store, on the top most shelf, sits a sealed jar filled with red fingers of light. One day I will open it and the chillies will flicker to the ground and blaze".

What do these lines signify.

I Above all Divakaruni makes this novel equally romantic with the introduction of the character the Lonely American, as Tilo calls him. He usually comes on Friday evenings. He wears a black colored pant, a plain black expensive leather jacket and a pair of black shoes. He stands slim and easy hipped, a casual hand slipped into a pocket rocking back a little on his heels. He has a sharp jaw-line, arresting, tilted cheekbones hinting stubbornness, blue back hair falling onto his forehead in careless elegance. The time when she first him the real nature of her womanhood is revealed. She is very much attracted by him. Though she was warned by the spices she likes to have him, losing control over herself and even the spices.

When the American touches her hand she cannot describe it in words. This touch goes through like a blade of fire .Yet, so sweet that she wants the hurting never to stop. Though she snatches her hand as obedient to mistress' the sensation stays. Unknowingly she waits for him and enjoys his company as a natural girl. When asked by Tilo, the American recollects his childhood .How his mother used to maintain everything clean and neat, how she loved him and so on. He considers everything about his mother was so good even her name Celestine, only later when he realizes that everything along with her name is fake, he hates her like anything. Till that time he believed himself to be a true American but now he realizes that he is not a true American and his name is RAVEN .He feels that they are responsible for his grandfather's death and from then onwards he always feels hurting, confused and angry. And comes to a conclusion that everyone has two sides some are not like that what they look later he tried to catch what his grandfather tried to give him at his death bed but lost because his mother snatched him away i.e. the POWER. He found that power lies in nothing but money at the center of the world. He understood its strange logic and its language which brought him power and its solidity and enjoyed it but without no body to share his success or feelings and so his golden life lost its glitter. He tried every physical thing to gain happiness but nothing gave him satisfaction. On one of his dreams he tried to kill himself from a hill top but was saved suddenly by a raven. Though he does not understand this dream he feels that his happiness lies in going to the earthly paradise. It haunted him for a while and slowly he returned to normal life considering it to be the fever hallucination. But it has been repeating now-a-days as he met Tilo-the old woman in the spice bazaar on some one's advice. He invites her to accompany him to find out earthly paradise.

As a Mistress one should not touch others but Tilo has crossed this rule many times, once she touched Lalitha to console and comfort her, later she was touched by the American when her finger was cut while she was cutting kalojire for Haroun. She tries many times to offer kalojire to protect haroun from the evil eyes but every time she fails. One night when haroun found the American in the store and asked Tilo to send him away, Tilo rejects saying she can take care of herself. From then she fails to meet haroun and he too never met her. As a Mistress of spices she must feel other's pain and leave her own passions behind, but from the time she was attracted by the American, spices start working against her as well as the persons to which they were used As a result of which geeta was separated from her family. Feeling responsible for these actions Tilo tries to meet geeta and tries to unite her with the family members. In this process she stepped out of the store - breaking another rule of mistress' So as to meet geeta she tries to prepare clothes of American style out of khus khus seeds but fails as spices do not cooperate her. Then she went to sears and takes all the worldly items with a want but puts away everything again and takes a pair of American clothes to wear to geetha and also a mirror the most forbidden thing for mistress'

First mother appears that night and warns her saying "if you try to help outside the protected walls turns on itself. Tilo then decides not to see outside even out of window. That day when mirror was delivered to her she covers it with a picture and sets to a nail for which the spices speak to her saying "Why not Tilo, our foolish mistress for what then did you buy it". Tilo feels very happy and says to herself over and over "Spices trust me, give me a chance. Inspite of America, or inspite of love, your Tilo will not let you down". But she once again steps out of 
the store to meet haroun and provide him kalojire. Meanwhile American meets her and offers her a white dress which settles on her like the petals of lotus. And in his company she tastes a bit of wine too. By the time she met haroun and returned back to the store she had a message revealing that "Shampathis fire is calling back and she has been left only three days for decision'

Tilo then tries to dispose of the commodities of the spice bazaar. In the second last night she asks the spices to give her such a beauty for one night in such a way that after spending with her he would never be with another woman without remembrance and regret. On the last day of sale she got plenty of money as nothing could be given free. As she grew young and beautiful because of the spices she introduces herself as the niece of the old woman. Meanwhile she gave the money to jagjit saying "use power, don't be used by it " and advises him to go to kwesi to learn the marshal arts with the money she gave.

As she had no time and no other way she uses red chillies to cureHaroun. but changes her mind at the last minute and offers lotus root to hameeda for passionate love. She brings back the pack of red chillies without giving them to haroun but the spices ask her as they have been roused they must work their power and something must bedestroyed. Though mistress sings the chant of propriation and asks to travel the path of forgiveness they reveal that as she had played without understanding the forces everything around her will be destroyed. She says, ' if destruction is a must then start with me,' to which they reply it is not hate but their duty. Tilo then makes love to the American and their desire has been satisfied. Writing a note and placing it near the paste Tilo asks the American to drop her at her place and come back in the morning.

Returning to the store she collects all the left overs in the store and made a pyre in the centre of the room and sprinkles sesame all over to protect her through journey and invokes words but nothing happens. She fears if she has been doomed to live as old woman without power and livelihood and plans to end herself from climbing the red goldgirdens of the bridge. ,but finally decides to accept the decree of spices. She willingly accepts it and firmly believes that she had not sinned but acted out of love. She recollects the story of Shiva - halahal - Tor one to be happy another must take upon the suffering'. She is ready to take whatever burden they lay but needs one hour of sleep saying so she lies down.

After a while, when she heard Raven, she was in a confusion whether she was dead or alive but spices speak to her saying that as she accepted the punishment in mind without battling that was enough for her and no need to undergo any physical punishment. Now she was neither like the old mistress nor like the young lady of the last day. But a moderate woman-just as Raven imagined her to be.

In search of earthly paradise when they crossed a tollbooth she heard about the destruction of the earthquake caused in Oakland. Looking into the water she recollects the destruction caused by her in the village during her childhood. She feels the responsibility and decides to go back to Oakland instead of with Raven. For in the end some things are most important than one's own joy.

\section{CONClusion}

There is an inevitable breakdown of communication and emotional estrangement that leads to unhappiness and tragedy. How these gaps will be filled up with cordial atmosphere? Who should take initiative steps to overcome these tense state?

Certainly, it is women or wife. Husbands are not oppressors. In the conventional sense problems arise because each of the women, endowed with a heightened awareness, wishes to be treated as an individual and merely as a wife. This is one of the areas where male domination operates.

By depicting her woman protagonists with their family set ups, fighting repressive social structures, she needs to prove her innocence emerging as an independent woman who finds inner harmony and happiness as her own terms.

Raven too promises to go with Tilo and tries to find earthly paradise in her presence. Then she asks Raven to find a name which suits to be both American as well as Indian as life for her is over as Tilo. 
Raven suggests the name of MAYA which means many things -Illusion, Spell, enchantment the power that keeps this imperfect world going day after day.

They go hand in hand towards car.

\section{REFERENCES}

[1] Chitra Benerjee Divakaruni, "The Mistress of spices", Swan Publications, London - 1998

[2] Chitra Benerjee Divakaruni, "Sister of my heart", Black Swan publications, London-1998

[3] Chitra Benerjee Divakaruni, op.cit.,p.208

[4] Ibid., p.58

[5] Ibid.

[6] Op.cit.,p.238

[7] Keki.N.Daruwalla, op.cit.,p.231

\section{AUTHOR'S BIOGRAPHY}

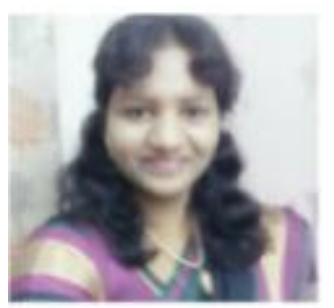

Chilka Aruna, as a Lecturer in English have been rendering services to the prestigious institution Hindu College, Guntur since 2000. In 2008, I became the Head of the Department. Coming to my personal profile, I have been awarded the A.P.STATE BEST TEACHER AWARD in 2015. Twelve of my research articles have been published in different souvenirs. I feel proud to say that I have been awarded the GURU BRAHMA NATIONAL AWARD-2016 by the MOTHER THERESA SOCIAL WELFARE ORG. (Regd.No:649/2010) in the year 2016. I have participated in various National \& International seminars and workshops. Thus I have enriched my language skills as well as teaching skills. Once again I feel proud to say that I have exchanged my views regarding literature and language with popular literary figures and experts in communication skills. 